\title{
ASPECTS REGARDING THE ENERGITICAL VALORIFICATION OF URBAN SLUDGE TREATMENT
}

\author{
DANA-CLAUDIA FARCAȘ-FLAMAROPOL ${ }^{1}$, ELENA SURDU ${ }^{*}$, ION DURBAC $\breve{C}^{1}$, \\ ANDREEA NIȚU ${ }^{1}$, RAMONA MARE ${ }^{1}$, EUGEN DUȚU ${ }^{2}$ \\ ${ }^{1}$, Politehnica” University of Bucharest, Faculty of Mechanical Engineering and \\ Mechatronics, Spl. Independenței street, 313, Bucharest \\ 2 “Radu Voda” Theoretical High School, Pătârlagele, Buzău
}

\begin{abstract}
This paper highlights through the issues addressed, the application aspects regarding the approach of the concept of recovery of sewage sludge from an urban wastewater treatment plant (SEAU), which is in a stage of technological expansion and modernization. Thus, it is considered the need to process the potential of biological mass generated by anaerobic stabilization in the SEAU, with a population of about 10,000 equivalent inhabitants, which requires on one hand, the technological design of activated sludge basins and on the other hand, the design of a sewage sludge fermentation tank, in order to produce biogas, necessary for its recovery for energy purposes.
\end{abstract}

Keywords: basin, activated sludge, wastewater, purge, ferment

\section{INTRODUCTIVE CONSIDERATIONS}

Civilization's progress, the increase in the standard of living, manifest a pronounced pollution of air [1], of water and soil, this way being imposed technical measures, economical and legal, specific. In this regard is being concluded the increase in the wastewater quality and, implicit, of the quantities of sludge that result from their treatment in the sewage treatment plants. The utilization of sewage sludge represents one of the most important challenges in wastewater management. Sludge contains nutrients (especially N, P, K) and organic matter that represents and agronomic benefit. The fact that the sludge doesn't contain heavy metals allows its utilization as fertilizer for the cultivated soil. Bacterial and fungal microflora of sludge has values similar to the ones of compost, dimension and composition of microorganism's population is very close to the one of soils [2-5].

The term "urban sludge" refers to the residual sludge from the wastewater treatment installations that use urban wastewater and residual sludge from septic tanks and other similar household water treatment stations [5].

Sludge represents waste, more or less harmful which have different origins and must be treated, stored or incinerated. The purging process is very complex, and therefore it must receive a lot of attention especially at the polyphaser fluids flowing in the installations, with the purpose of optimizing energy consumption [6].

Many researchers say that in the future urban sludge neutralization through the soil - considered as a biological purging station (purging system, without affecting its fertility for the moment and for a long period of time).

\footnotetext{
* Corresponding author, email: elena.surdu@yahoo.com

(C) 2021 Alma Mater Publishing House
} 
The pollution effect produced by the untreated or insufficiently treated wastewater to the surface water manifests mainly by the content of suspended matter, organic matter, in nutritive salts, ammonium and in pathogen microorganisms [7]. Advanced and efficient control strategies of the biological [8, 9], chemical and mechanic wastewater purging processes are being imposed [10]. Mechanical and chemical purging results in the elimination, in the first step, of the solid settle able substances and the oils that float, and in the second step, the biological one, the elimination of almost all the organic dissolved substances [11].

For humans, water is a vital source, such that the researches in the water composition domain and in the efficient filtration domain are extremely important [12].

For achieving EU's requests significant investments were made in Romania in the last years to extend, modernize and build urban wastewater purging stations [13].

The process of biological treatment with activated sludge was discovered in 1914 and first applied in 1916 at Worcester [13]. The term activated sludge was introduced by Arden and Lockett. They consider that a sufficiently aerated and agitated polluted water, in the presence of microorganisms can self-purify [14]. At this stage there are mixtures of activated sludge and wastewater, air and wastewater, activated sludge and air. Due to these mixtures, there are problems related to the transfer of oxygen needed for treatment in wastewater.

For the treatment of industrial and domestic wastewater is used the most common, but also the oldest process of aerobic biological treatment, the conventional one with activated sludge. This process can be carried out in several ways, according to various schemes that differ by [15]:

- The flow pattern;

- The resulting amount of sludge;

- The specific loading of activated sludge, etc.

Thus, there are: the classic scheme, with continuous feeding, of low load, the one with the loading in several points along the reactor, and the one of the wastewater treatments in two stages, in which two conventional biological treatment stages are connected in series [15].

A more current technology is the use of sequential basin reactions (SBR). These scrubbers use saturated and dry activated sludge as a scrubbing process. The system consists of a single basin in which the processes (equalization, aeration and settling) take place cyclically. Among the advantages of this system is the control of the flow to be treated. An SBR basin serves as an equalization basin during filling so it can easily tolerate high values of wastewater flows. By changing the system configuration, the bioreactor with fluidized medium was obtained. Other advantages: increased sludge stabilization, basins can be designed for vertical expansion and can be assembled in hard to reach places. Excess sludge generated by bio-chemical reactions is discharged from the SBR during or after the settling process using pumps for excess sludge. Occasionally, when differential heads are available, sludge is removed by mechanical (or manual) valve opening and gravitational discharge to the aerobic digestion basin, sludge drying beds, or other purification processes [16].

The latest technology for the biological degradation of soluble organic impurities is the membrane bioreactor (MBR). This type is a version of the conventional activated sludge (CAS) system. While CAS uses a settling tank for solid-liquid separation, an MBR uses a membrane that offers a number of advantages related to process control and water quality, such as small surface area and easy modernization [16]. The major disadvantage that prevents the wider application of MBRs is the fouling of membranes, which significantly reduces their performance and lifespan, resulting in a significant increase in maintenance and operating costs. There are two MBR configurations: internal/submerged, in which the membranes are submerged and integrated in the biological reactor and external/lateral flow, where the membranes are a separate unit process that requires an intermediate pumping stage. In this method the activated sludge is not separated and recirculated in the secondary aerator, but refrained in the aeration basin with the help of membrane filters. In this way the biomass concentration is increasing three or four times.

The amount of sludge, which results from the processes of treatment and purge of wastewater in urban purging plants is large and the tendency is to be capitalized so as to obtain technical and economic advantages.

This concept of capitalization of purging sludge was the basis for the initiation of an investment project that could aim at the expansion and technological modernization of a wastewater treatment plant (WWTP) in a locality. 
Taking in consideration all of the above said, this article highlights the application aspects related to the technological design of activated sludge basins.

\section{TECHNOLOGICAL DESIGN OF ACTIVATED SLUDGE BASINS}

\subsection{Theoretical brief}

Basins with activated sludge, also called aeration basins, are used in the biological wastewater treatment stage when mixing the following elements: wastewater, air and activated sludge (Figure 1).

To achieve this mixture, regardless of the aeration process, the following conditions must be met [17]:

- The introduction into the aeration basin of the amount of oxygen necessary for the development of bio-chemical processes.

- In the case of the three elements, wastewater, air and active recirculation sludge, a good and efficient homogenization must be achieved.

- Avoid depositing mud flakes at any point in the aeration basin.

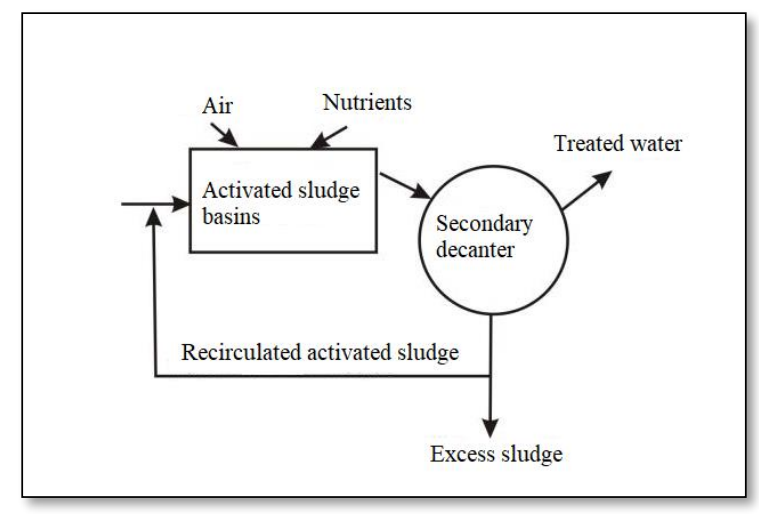

Fig. 1. General scheme of conventional sludge treatment with activated sludge basins (ASB) [18].

The bacteria participating in the process are of the aerobic type, are found in the wastewater decanted in the primary stage and do not always adapt to the aerobic conditions in the activated sludge basin. In this basin, conditions for the development and multiplication of microorganisms are artificially created, which transform biodegradable organic substances into living cellular material. This material is transformed into flakes that are retained in the secondary decanters and are called "activated sludge".

The efficiency of this process depends on the type of treatment adopted, the nature of the wastewater, the aeration processes applied and varies between 60 and $98 \%$.

Basins with activated sludge are generally uncovered, being constructions of reinforced concrete or metal of rectangular, circular, annular and mixed shape (rectangular with semicircular ends), buried, semi-buried or above ground, depending on the solution adopted.

The main components of the activated sludge basins (Figure 2) are:

- The basin in which the process takes place;

- Air transmission and distribution pipes and air blowing devices (diffusers, panels, tubes);

- Support and access bridges for the aeration systems, the adjusting valves placed on the air and wastewater pipes, the measuring and control equipment;

- The measuring, control and automatization equipment;

- Wastewater and recirculation sludge access and evacuation pipes and paths in/from the aeration basins.

In order, to design an activated sludge basin, the design parameters common to all types of basins are established, those corresponding to pneumatically aerated and mechanically aerated basins, sometimes even special parameters for each type of basin. 
The design parameters common to activated sludge basins are generally used to determine the volume of basins, the amounts of recirculation and excess sludge, and the oxygen required.

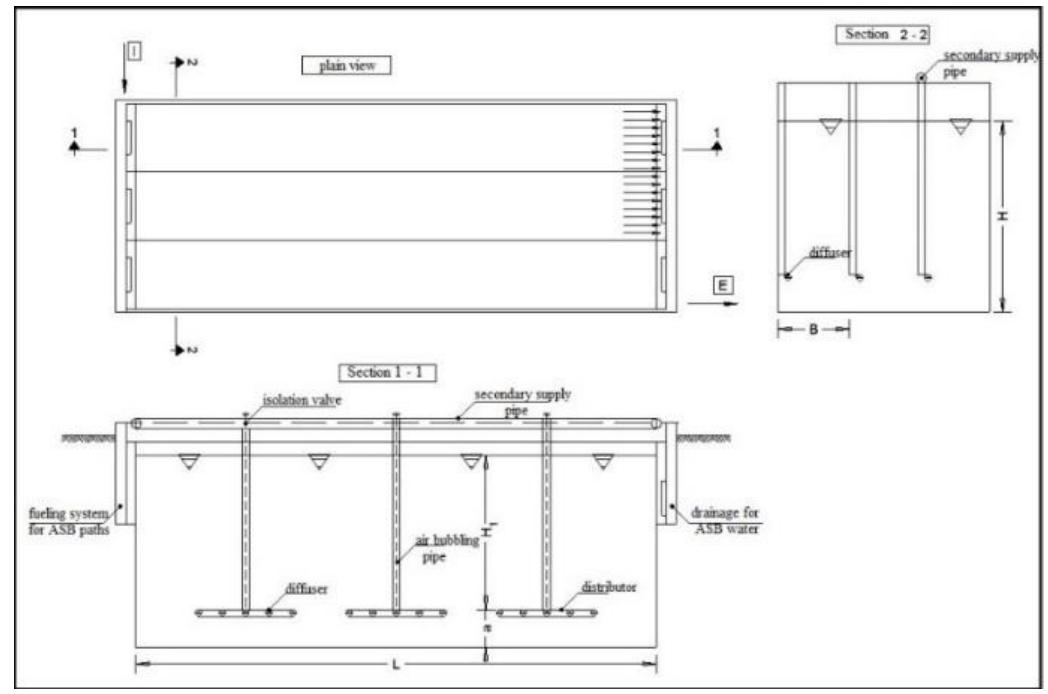

Fig. 2. Active Sludge Basin [17].

The design parameters of the activated sludge basins necessary for the calculation, depending on the required treatment (with sludge stabilization, with nitrification), are presented in the bibliographic source [17].

The organic load of the Iob basin, according to the bibliographic source [17], is recommended to be established according to the degree of purification required, according to the relation:

$$
\mathrm{I}_{o b}=5 \cdot \sqrt{1-\beta} \quad\left[\mathrm{kg} \mathrm{BOD}_{5} / \mathrm{m}^{3} \text { basin, } \mathrm{h}\right]
$$

in which $\beta$ is the necessary purging grade.

The load of organic sludge $\left(\mathrm{L}_{\mathrm{os}}\right)$, represents the ratio between the organic load of the basin and the concentration of dry solids. According to some authors [18], the empirical relation can also be used:

$$
\mathrm{I}_{\text {on }}=5 \cdot(1-\beta) \quad\left[\mathrm{kg} \mathrm{BOD}_{5} / \mathrm{kg} \text { solid dry substance } \mathrm{h}\right]
$$

For this parameter it is recommended [4] that for purging grades between $85-90$ [\%] should be considered $I_{o n}=$ $0.02 \ldots 0.04[\mathrm{~kg} \mathrm{BOD} 5 / \mathrm{kg} \mathrm{C}, \mathrm{h}]$, and for purging grades between $60-80[\%]$ should be taken $0.03-0.10$ [kg BOD $/ \mathrm{kg} \mathrm{C}, \mathrm{h}][17]$.

The hydraulic loading of a basin (HL) is a verification parameter of the basin's dimensions with activated sludge and is calculated with the relation:

$$
\mathrm{I}_{h}=\frac{Q}{V_{b}}
$$

in which: $Q$ represents the total quantity of wastewater $\left[\mathrm{m}^{3}\right], V_{b}-$ active sludge's basin volume $\left[\mathrm{m}^{3}\right]$.

According to the same source in literature [17], hydraulic loading should take into account the values of the dependencies between the total amount of wastewater and the volume of the basin, as follows:

- $10.00-20.00$ [ $\mathrm{m}^{3}$ wastewater], for $1.00 \mathrm{~m}^{3}$ aeration basin, day, at purging grades $\beta$ between $85-90$ [\%];

- $20.00-50.00$ [ $\mathrm{m}^{3}$ wastewater], at purging grades $\beta$ between $60-80$ [\%].

Concentration of suspended solids in the pool mixture (C), varies in general, between $600-4000\left[\mathrm{mg} / \mathrm{dm}^{3}\right]$, representing in percentage, related to the fluid in the basin, values between $0.6-4.0$ [\%]. In literature [17] the values presented in Tabel 1 are proposed. For the calculation of the $\mathrm{C}$ parameter the calculation relation is: 


$$
\mathrm{C}=\frac{\mathrm{I}_{o n}}{\mathrm{I}_{o b}}=\frac{5 \cdot \sqrt{1-\beta}}{5 \cdot(1-\beta)}=\frac{1}{\sqrt{1-\beta}} \quad\left[\mathrm{kg} / \mathrm{m}^{3}\right]
$$

Sludge Index $\left(\mathrm{I}_{\mathrm{S}}\right)$, is a parameter according to which, from literature [1], the following values are recommended: - $\mathrm{I}_{\mathrm{n}}=100 \ldots 150[\mathrm{ml} / \mathrm{g}]$, for purging grades $\beta$ between $60-75[\%]$

$-\mathrm{I}_{\mathrm{n}}=75 \ldots 100[\mathrm{ml} / \mathrm{g}]$, for purging grades $\beta$ between $90-97[\%]$

- $\mathrm{I}_{\mathrm{n}}=50[\mathrm{ml} / \mathrm{g}]$, for a purging grade $\beta=98[\%]$ (mineralization, sludge stabilization).

Percentage of recirculation sludge $\left(\mathrm{P}_{n r}\right)$. It was found that there is a direct link between the percentage of recirculating sludge $\mathrm{P}_{\mathrm{nr}}$, the sludge index In and the concentration of suspended solids, $\mathrm{C}$ in the basin. Thus, as $\mathrm{C}$ increases, so does $\mathrm{P}_{\mathrm{nr}}$; or for the same $\mathrm{C}$ with the increase of $\mathrm{In}$, increases also Pnr etc. These interdependencies are expressed by the equation (5):

$$
\mathrm{P}_{n r}=\frac{100 \cdot \mathrm{C} \cdot \mathrm{I}_{n}}{100 \cdot \mathrm{C} \cdot \mathrm{I}_{n}}
$$

The concentration of dry solids in the recirculation sludge $(\mathrm{Cr})$ depends on the concentration of dry solids in the basin $(C)$ and the percentage of recirculation sludge $\left(\mathrm{P}_{\mathrm{nr}}\right)$, and the excess sludge $\left(\mathrm{N}_{\mathrm{ex}}\right)$ is a parameter for which literature sources [1] recommend the use of the calculation equation [17]:

$$
\mathrm{N}_{e x}=\sqrt[4]{5 \cdot(1-\beta)} \quad\left[\mathrm{kg} \text { dry solids in the recirculation sludge } / \mathrm{kg} \text { of } \mathrm{BOD}_{5}\right]
$$

The required oxygen $(\mathrm{Ro})$, after $[17,18]$ represents the parameter for which the total oxygen consumption per hour has been established, with the equation:

$$
\mathrm{O}_{n}=0.5 \cdot \beta \cdot \mathrm{C}_{0}+0.1 \cdot \mathrm{P}_{m g}^{\prime} \quad\left[\mathrm{kg} \mathrm{O}_{2} / \mathrm{h}\right]
$$

in which: $\beta$ is the purging degree of the biological stage, $C_{0}$ is total quantity of $B O D_{5}$ entered into the activated sludge basin in one day $[\mathrm{kg}], \mathrm{P}_{\mathrm{mg}}^{\prime}$ is the amount of dry solids that take part in the treatment during a hour [kg].

From source [17], the amount of $O_{2}[\mathrm{~kg}]$ can be determined for one $\mathrm{kg}$ of $B O D_{5}$ entered into the basin, with relation:

$$
\frac{\mathrm{O}_{\mathrm{n}}}{\mathrm{C}_{0}}=0.5 \cdot \beta \cdot \mathrm{C}_{0}+\frac{0.02}{1-\beta} \quad\left[\mathrm{kg} \mathrm{O}_{2} / \mathrm{kg} \mathrm{BOD}_{5} \text { entered into the basin }\right]
$$

If it is accepted that for one inhabitant, the amount of $\mathrm{BOD}_{5}$ entering the biological treatment is 35 [g/resident, day], for a treatment of 90 [\%], in the activated sludge basin an amount of 31.5 [g BOD 5 ] must be removed, which requires an amount of air, $0.042\left[\mathrm{~m}^{3} /\right.$ resident, $\left.\mathrm{h}\right]$.

Table 1 shows the quantities of air per $\mathrm{kg}$ of $\mathrm{BOD}_{5}$ removed per inhabitant per day, for an air blowing depth of $3.00 \mathrm{~m}$.

Table 1. Necessary Volume of Air for Pneumatic Aeration [17]

\begin{tabular}{|l|c|c|c||}
\hline \multirow{2}{*}{\begin{tabular}{c}
\multirow{2}{*}{ Type of aeration } \\
Fine Bubbles Diffusers
\end{tabular}} & $\begin{array}{c}\text { Oxygen Utilization } \\
\text { efficiency, [\%] }\end{array}$ & At 1 [kg] of BOD 5 removed & For 1 [resident $/ \mathrm{h}]$ \\
\cline { 3 - 4 } & 11 & 32.50 & 0.042 \\
\hline \hline Medium Bubbles Diffusers & 6.5 & 55.00 & 0.072 \\
\hline Large Bubbles Diffusers & 5.5 & 65.00 & 0.085 \\
\hline
\end{tabular}

The oxygenation capacity of $\mathrm{CO}_{10}$ is determined by the relationship:

$$
\mathrm{CO}_{10}=\mathrm{O}_{n} \cdot \frac{c_{s(10)}}{c_{S(\theta)}-c_{0}} \cdot \frac{760}{p} \cdot \frac{K_{10}}{K_{\theta}} \cdot \frac{a_{1}}{a_{2}} \quad\left[\mathrm{kgO} O_{2} / \mathrm{h}\right]
$$

Using relationship (8), for $\theta=23{ }^{\circ} \mathrm{C}, \mathrm{c}_{0}=2, \mathrm{a}_{1}=1.25, \mathrm{a}_{2}=0.85$, results $\mathrm{CO}_{10}=2 \mathrm{O}_{\mathrm{n}}$, and for $\theta=15^{\circ} \mathrm{C}, \mathrm{c}_{0}=1.50$, $\mathrm{a}_{1}=1.20, \mathrm{a}_{2}=0.93$, results $\mathrm{CO}_{10}=1.5 \mathrm{O}_{\mathrm{n}}$. 


\section{RESULTS AND DISCUSSION}

The design data used to determine the size of the pool were:

- $\mathrm{BOD}_{5}$ at the entrance into the basin: $0.15\left[\mathrm{~kg} / \mathrm{m}^{3}\right]$;

- $\mathrm{BOD}_{5}$ at the exit out of the secondary decanters: $0.02\left[\mathrm{~kg} / \mathrm{m}^{3}\right]$;

- The concentration of solids at the entrance into the activated sludge basin, $c=0.12\left[\mathrm{~kg} / \mathrm{m}^{3}\right]$;

- Daily quantity of wastewater $\mathrm{Q}=25.000 \mathrm{~m}^{3}$ wastewater;

$-\mathrm{N}_{\mathrm{ex}}=0.85\left[\mathrm{~kg} / \mathrm{m}^{3}\right]$;

$-\mathrm{O}_{\mathrm{n}}=1.12\left[\mathrm{~kg} / \mathrm{m}^{3}\right]$;

$-\mathrm{CO}_{\mathrm{c}}=1.43[-]$

$-\mathrm{CO}_{\mathrm{p}}=2.00[-]$

$-\mathrm{I}_{\mathrm{on}}=0.30[-]$

$-\mathrm{I}_{\mathrm{n}}=0.150[\mathrm{l} / \mathrm{g}]$

$-\mathrm{P}_{\mathrm{nr}}=100[\%]$;

- $\mathrm{C}=0.003\left[\mathrm{~kg} / \mathrm{m}^{3}\right](0.33 \%)$;

$-\mathrm{I}_{\mathrm{ob}}=0.041\left[\mathrm{~kg} / \mathrm{N} \mathrm{m}^{3} \cdot \mathrm{h}\right]$;

- Quantity of $\mathrm{BOD}_{5}$ entered in one day into the activated sludge basin: $\mathrm{C}_{0}=156.25[\mathrm{~kg} / \mathrm{h}]$;

- Quantity of necesary $\mathrm{O}_{2}$ introduced daily, it is determined as following: $\mathrm{O}_{\mathrm{n}}=312.50\left[\mathrm{~kg} \mathrm{O}_{2} / \mathrm{h}\right]$;

- The aeration type $t_{a}$, according to some sources [1], it is calculated with the relation:

$$
t_{a}=\frac{24 \cdot V}{Q}=3.6
$$

It is recommended not to exceed the aeration time values specified in Table 1. According to source [17], the aeration time must be greater than $3[\mathrm{~h}]$, which confirms the result obtained.

- The age of the $\mathrm{mud}\left(V_{n}\right)$, according to [17], it is determined with the following relation:

$$
\mathrm{V}_{\mathrm{n}}=\frac{\mathrm{C} \cdot \mathrm{t}_{\mathrm{a}}}{24 \cdot \mathrm{c}}=106
$$

in which, $C$ is the concentration of solids in suspension at the entrance to the activated sludge basin. The obtained value is close to the one in Table 1.

- The volume of the basin with activated sludge is determined from relation:

$$
\mathrm{V}_{b}=\frac{\mathrm{C}_{0}}{\mathrm{I}_{o b}} \quad\left[\mathrm{~m}^{3}\right]
$$

in which: $\mathrm{C}_{0}=156[\mathrm{~kg} / \mathrm{h}]$ (total quantity of $\mathrm{BOD}_{5}$ entered into the basin in an hour; $\mathrm{I}_{\mathrm{ob}}=0.041\left[\mathrm{~kg} \mathrm{BOD}_{5} / \mathrm{m}^{3}, \mathrm{~h}\right]$ (basin's organic load). So it turns out: $\mathrm{V}_{\mathrm{b}}=3804\left[\mathrm{~m}^{3}\right]$.

- Hydraulic load is determined with relation (3), from above, resulting a value close to the one in Table 1:

$$
I_{h}=\frac{Q}{V_{b}}=\frac{25000}{3804}=6.57
$$

In almost all treatment plants, the volume of activated sludge tanks exceeding $150 \mathrm{~m}^{3}$ is divided into two or more units, which operate independently. Also, if the volume exceeds $75 \mathrm{~m}^{3}$, there should be two secondary decanters. In large treatment plants, activated sludge tanks and secondary decanters are arranged in two or more independent units (batteries) in order, to ensure flexible operation. The volume of each battery is divided into several compartments through side walls, forming a kind of channels. It is recommended that in cross section the width of the basin (B [m]) does not exceed twice its height $(\mathrm{H}[\mathrm{m}])$.

The heights vary between $3.00-5.00$ [m], so the maximum widths are between $6.00-10.00[\mathrm{~m}]$. The choice of height depends on the possibility and conditions of air supply to the pool. Many pools are equal in width and height. The ratio between the length and the width of the channels should be between 5:1 - 10:1, in order to minimize the danger of short-circuit of the pool. The length of the channels is between $30-100$ [m]. 
Appling the relations from the mathematical model presented, for the input values $\mathrm{H}=4 \mathrm{~m}$, we obtain:

- Width: $B=1.50 \cdot H=6.00[\mathrm{~m}]$;

- Cross area: $A_{t r}=B \cdot H=24.00\left[\mathrm{~m}^{2}\right]$;

- Length: $L=V / A_{t r}=3750 / 24=156[\mathrm{~m}]$.

To meet the condition of the ratio: $\mathrm{B} / \mathrm{L}^{`}=1 / 7$ (recommended: $1 / 5-1 / 10$ ) is need two batteries with two channels each with a length $\mathrm{L}=40.00 \mathrm{~m}$.

The design characteristics of aeration devices (oxygenation) must take into account the oxygenation capacities $\left(\mathrm{CO}_{10}\right)$ and aeration efficiencies of activated sludge tanks. In the case of pneumatic aeration, the oxygenation capacities $\left(\mathrm{CO}_{10}\right)$ and aeration efficiencies (energy index $\left[\mathrm{kg} \mathrm{O}_{2} / \mathrm{kWh}\right]$ ) of aeration devices in activated sludge tanks for different bubble sizes (fine, medium and large) are given in Table 2 below., both for clean water and for wastewater. The amount of oxygen introduced must be the greater the depth and the smaller the bubbles, and vice versa.

Table 2. Oxygenation Capacities $\left(\mathrm{CO}_{10}\right)$ and aeration efficiency (energetic index) of the diffusers from the activated sludge basins with pneumatic aeration [17]

\begin{tabular}{|c|c|c|c|c|c|}
\hline \multirow[b]{2}{*}{ Aeration type } & \multirow[b]{2}{*}{$\begin{array}{l}\text { Working } \\
\text { conditions }\end{array}$} & \multicolumn{2}{|c|}{ Recommended values } & \multicolumn{2}{|c|}{ Average values } \\
\hline & & $\begin{array}{c}\text { Introduced } \mathrm{O}_{2} \\
\left(\mathrm{CO}_{10}\right)\left[\mathrm{kg} \mathrm{O}_{2} / \mathrm{N}\right. \\
\mathrm{m}^{3} \text { air } \cdot \mathrm{m} \text { basin } \\
\text { depth] }\end{array}$ & $\begin{array}{c}\text { Used } \mathrm{O}_{2} \\
{\left[\mathrm{~kg} \mathrm{O}_{2} /\right.} \\
\mathrm{kWh}]\end{array}$ & $\begin{array}{c}\text { Introduced } \mathrm{O}_{2} \\
\left(\mathrm{CO}_{10}\right)\left[\mathrm{kg} \mathrm{O}_{2} / \mathrm{N}\right. \\
\mathrm{m}^{3} \text { air } \cdot \mathrm{m} \text { basin } \\
\text { depth] }\end{array}$ & $\begin{array}{c}\text { Used } \mathrm{O}_{2} \\
{\left[\mathrm{~kg} \mathrm{O}_{2} /\right.} \\
\mathrm{kWh}]\end{array}$ \\
\hline \multirow{2}{*}{$\begin{array}{l}\text { Fine bubbles aeration } \\
\qquad d_{b} \leq 3 \mathrm{~mm}\end{array}$} & Clean water & 0.12 & 2.2 & 0.10 & 1.7 \\
\hline & Wastewater & 0.10 & 1.8 & 0.008 & 1.3 \\
\hline \multirow{2}{*}{$\begin{array}{l}\text { Medium bubbles aeration } \\
\qquad d_{b}=4-6 \mathrm{~mm}\end{array}$} & Clean water & 0.007 & 1.4 & 0.006 & 1.1 \\
\hline & Wastewater & 0.005 & 1.1 & 0.004 & 0.8 \\
\hline $\begin{array}{l}\text { Large bubbles aeration } \\
\qquad d_{b}>6 \mathrm{~mm}\end{array}$ & Clean water & 0.006 & 1.2 & 0.005 & 0.9 \\
\hline
\end{tabular}

Therefore, the basins with activated sludge will be designed in the pneumatic aeration variant, through porous plates (fine bubbles, $\mathrm{db} \leq 3 \mathrm{~mm}$ ) with dimensions: $300 \times 300 \times 25 \ldots 40 \mathrm{~mm}$, which is located on the basin screed (Figure 3).

Maximum air quantity is calculated, $Q_{\max , a e r}$, with relation:

$$
\mathrm{Q}_{\text {max,aer }}=\frac{\mathrm{O}_{n}}{\mathrm{O}_{n}^{*}}=8446 \quad\left[\mathrm{Nm}^{3} \mathrm{air} / \mathrm{h}\right]
$$

in which $O_{n}^{*}$ is the amount of oxygen introduced into the height $\mathrm{H}^{\prime}=3.70[\mathrm{~m}]$ (the laying depth of the porous plates, at $0.30 \mathrm{~m}$ from the screed), and the oxygenation capacity, according to Table 3 , for wastewater is $C O_{10}=$ $0.10\left[\mathrm{~kg} O_{2} / \mathrm{N} \mathrm{m}^{3}\right.$ air $\left.\cdot \mathrm{m}\right]$.

Brut energy $E_{b}$, will require a consumption of (relation 15) for used energy $E_{c}=5.5\left[\mathrm{Wh} / \mathrm{m}^{3}\right]$ :

$$
E_{b}=\mathrm{H}^{\prime} \cdot \mathrm{E}_{c}=3.7 \cdot 5.5=20.35 \quad\left[\mathrm{Wh} / \mathrm{Nm}^{3} \text { air }\right]
$$




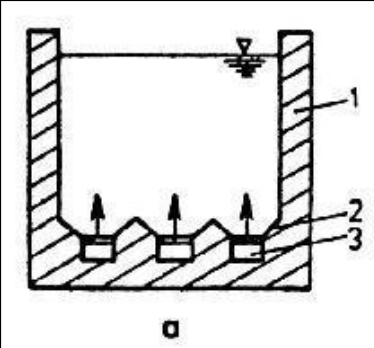

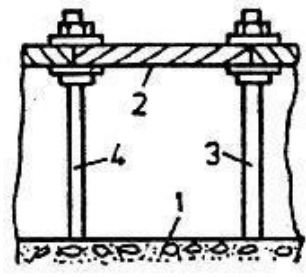

b

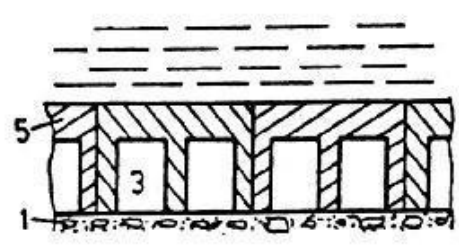

c

Fig. 3. Aeration basins with porous plates [18]:

a- basin with saw teeth and porous plates; b- installation detail of porous plates for a pool with horizontal eraser; c- mounting detail of porous bodies placed on a horizontal eraser; 1 - reinforced concrete basin; 2- porous plate; 3- channel of compressed air; 4- mounting bolt; 5- block type porous body.

The power required to raise a quantity of $2.80\left[\mathrm{Nm}^{3} \mathrm{air} / \mathrm{min}\right]$ at the required pressure, with an efficiency of 80 [\%] of the compressor and the consumed power for the purge of $158\left[\mathrm{~m}^{3} / \mathrm{h}\right]$, using $1.00\left[\mathrm{Nm}^{3}\right.$ air] for $0.13\left[\mathrm{~m}^{3}\right.$ wastewater] in Table 3.

Table 3. Necessary and used power in basins with activated sludge [17]

\begin{tabular}{|c|c|c|c|c|c|c|c|c|c|c|c|}
\hline $\begin{array}{c}\text { Compressor pressure } \\
{[\mathrm{MPa}]}\end{array}$ & $35 \cdot 10^{7}$ & $38.5 \cdot 10^{7}$ & $40 \cdot 10^{7}$ & $45.5 \cdot 10^{7}$ & $49 \cdot 10^{7}$ & $52.5 \cdot 10^{7}$ & $56 \cdot 10^{7}$ & $59.5 \cdot 10^{7}$ & $63 \cdot 10^{7}$ & $66.5 \cdot 10^{7}$ & $70 \cdot 10^{7}$ \\
\hline $\begin{array}{c}\text { The necessary } \\
\text { power [kW] }\end{array}$ & 1.83 & 1.98 & 2.13 & 2.28 & 2.42 & 2.57 & 2.72 & 2.86 & 3.01 & 3.16 & 3.30 \\
\hline $\begin{array}{c}\text { Power consumed } \\
{[\mathrm{kW}]}\end{array}$ & 301.5 & 330.9 & 353 & 382.4 & 404.5 & 433.9 & 456 & 478 & 507.4 & 551.6 & 551.6 \\
\hline
\end{tabular}

To calculate the power consumption and required $\mathrm{P}$ at the compressed air generator, the following calculation relations are used:

$$
\begin{array}{cc}
\mathrm{P}=\frac{34000 *\left(p^{0,29}-1\right) \cdot \mathrm{Q}}{75 * \eta_{c}} & {[\mathrm{~kW}]} \\
\mathrm{p}=\frac{10.3+\mathrm{H}_{\mathrm{c}}}{10.3} & {[\mathrm{~kW}]}
\end{array}
$$

The efficiency $\eta_{c}=65 \%$.

Sizing of porous media (plates):

- Eraser's Surface $A_{0}=160 \cdot 6=960\left[\mathrm{~m}^{2}\right]$;

- Aeration intensity $I_{a}=1.00\left[\mathrm{~N} \mathrm{~m}^{3}\right.$ air $\left./ \mathrm{m}^{2} \mathrm{~min}\right]$

- Area of aeration plates $S_{p a}$ :

$\mathrm{S}_{p a}=\frac{\mathrm{Q}_{\max , a e r}}{60} \cdot \mathrm{I}_{a}=140\left[\mathrm{~m}^{2}\right]$, which represents $14[\%]$ out of the eraser's surface. Recommended value should be between $10-20[\%]$.

The technical-economic operating parameters of the activated sludge basins must include the following specifications:

- Daily consumption of compressed air $Q_{z}\left[\mathrm{~N} \mathrm{~m}^{3}\right.$ air/h]:

$$
\mathrm{Q}_{\mathrm{z}}=\frac{\mathrm{CO}_{\mathrm{e}} \cdot \mathrm{V}_{\mathrm{b}}}{\mathrm{O}_{\mathrm{n}}^{*}}=\frac{1.43 \cdot 3804}{37} \cdot \frac{1000}{24}=6126 \quad\left[\mathrm{Nm}^{3} \mathrm{air} / \mathrm{h}\right]
$$

- The air flow $Q_{\text {nec, air }}\left[\mathrm{Nm}^{3}\right.$ air/ $\left.\mathrm{kg} \mathrm{BOD}{ }_{5}\right]$ corresponding to the active sludge basin with a volume of $V=3804$ [m $]$ and efficiency (the return) $\eta_{b}=90$ [\%], which can be determined with relation:

$$
Q_{\text {nec }, \text { aer }}=\frac{Q_{z}}{V_{b} \cdot \eta_{b}}=\frac{6126}{3804 \cdot 0.9}=1.78 \quad\left[\mathrm{Nm}^{3} \text { air } / \mathrm{kgBOD}_{5}\right]
$$


Used brut energy $E_{b c}$, has in sight the following calculation relationship:

$$
E_{b c}=Q_{n e c, a e r} * E_{b}=1.78 \cdot 36.41 \cdot 10^{-3}=0.06 \quad\left[\mathrm{kWh} / \mathrm{kg} \mathrm{BOD}{ }_{5}\right]
$$

Daily air flow $Q_{z}\left[\mathrm{~N} \mathrm{~m}^{3}\right.$ air/day], relative to the daily amount of wastewater $Q\left[\mathrm{~m}^{3}\right]$ :

$$
\frac{\mathrm{Q}_{z}}{\mathrm{Q}}=\frac{144932}{25000}=5.80 \quad\left[\mathrm{Nm}^{3} \text { air } / \mathrm{m}^{3} \text { wastwater }\right] .
$$

The power of the aeration compressor uses calculation equations (15) and (16):

$$
\begin{array}{ll}
\mathrm{P}=103.40 & {[\mathrm{~kW}]} \\
p=1.088 & {[\mathrm{~kW}]}
\end{array}
$$

\section{CONCLUSIONS}

This paper highlights through the issues addressed, the application aspects related to the technological design of activated sludge tanks, and a sludge fermentation tank will be designed in a future paper. in order to produce biogas necessary for its recovery for energy purposes.

The use of the potential biological mass generated through the anaerobic stabilization inside any urban mechanical biological purification plant with a population of over 10.000 inhabitants and respectively the transformation of those into biogas, representing an actual strategic option and at the same time the technical solution of the future to be adopted and generalized.

After designing the activated sludge basins two batteries have been obtained, each one having two canals with a length of $L^{\prime}=40,00[\mathrm{~m}]$, to fulfill the condition of the ratio: $B / L^{\prime}=1 / 7$. Basins with activated sludge have been designed in the pneumatic aeration type with porous plates (fine bubbles, $d_{b} \leq 3 \mathrm{~mm}$ ) with dimensions: $300 \times 300$ $\times 25 \ldots 40 \mathrm{~mm}$ that are placed on the basin's eraser. Pneumatic generators are air compressor type.

\section{REFERENCES}

[1] Durbacă, I., Echipamente pentru prevenirea poluării mediului, Editura Printech, București, 2011.

[2] Sumedrea, D., Cercetări privind aplicarea nămolurilor orăşeneşti ca fertilizant în pomicultură, Institutul de Cercetare - Dezvoltare pentru Pomicultură Piteşti - România, 2008.

[3] Leonard, I., Metodologie de utilizare a nămolului orâşenesc în agricultură, Editura SOLNESS, Timişoare, 2007.

[4] Cernii, O., Tratarea nămolurilor de la staţia de epurare a apelor uzate din oraşul Chişinău, Teză de disertaţie, Universitatea Tehnică a Moldovei, Chişinău, Republica Moldova, 2016.

[5] Pintea, I.I., Cercetări privind influenţa nămolurilor de la staţiile de epurare orăşeneşti asupra culturii de lucernă, Teză de doctorat, Universitatea de Ştiinţe Agricole şi Medicină Veterinară, Cluj - Napoca, 2012.

[6] Ionescu (Boncescu), C., Cercetări teoretice şi experimentale asupra curgerii fluidelor polifazate prin staţia de epurare în scopul optimzării energetice, Teză de doctorat, Universitatea PLOITEHNICA din Bucureşti, 2017.

[7] Panaitescu, M., Tehnici de epurare ape uzate, Indrumar de proiectare staţie de epurare, Editura Nautica, Constanţa, 2011.

[8] Luca, L., Strategii de control avansat al proceselor de epurare bilogică a apelor reziduale, Teză de doctorat, Universitatea Dunărea de Jos din Galaţi, 2018.

[9] Rusu, A.T., Metode avansate de epurare biologică a apelor uzate, A XVI - a Conferinţă internaţională multidisciplinară "Profesorul Dorin Pavel - fondatorul hidroenergeticii româneşti”, Sebeş. România, 2016, p. 443 -450 .

[10] ECSM 2019- $5^{\text {th }}$ European Conference on Sludge Management, University of Liège, Belgium, 6 - 8 October 2019, https://events.uliege.be/ecsm2019/ (19.04.2021).

[11] Radu, M.V., Ionescu, P., Biotehnologii integrate cu procese fizico-chimice pentru epurarea apelor uzate orăşeneşti şi pentru tratarea nămolurilor reziduale în vederea refolosirii, Ecoterra, no. 28, 2011, p. 149 - 154. 
[12] Dascălu, E.M., Studiu comparativ între membrane de nanofiltrare şi de osmoză inversă pentru tratarea eficientă a apei, Teză de doctorat, Universitatea "Vasile Alecsandri” din Bacău, 2018

[13] Iticescu, C., Optimal solutions for the use of sewage sludge on agricultural lands, Water, vol. 13, no. 585, 2012 , p. $1-15$.

[14] https://www.asio.ro/produse/statii-de-epurare-comunale-30-5000-le-9/statiile-de-epurare-as-hsbr-133.html (15.04.2021).

[15] http://ecotrust.ro/blog-ecotrust/69-variantele-procesului-de-epurare-cu-namol-activ (19.04.2021).

[16] https://upb.ro/wp-content/uploads/2017/11/Rezumat_ROBONCESCU.pdf (13.04.2021).

[17] Normativ - Proiectarea, executia și exploatarea sistemelor de alimentări cu apă şi canalizare a localităţilor, Partea a II-a: Epurarea apelor uzate, ICECON SA, UTCB, București, 2009.

[18] https://docplayer.ro/151657706-Construcții-de-tratarea-și-epurarea-apei-curs-prof-dr-oncia-silvica-1.html (13.04.2021). 